\title{
PENGEMBANGAN ALAT UKUR SUHU MENGGUNAKAN SENSOR LM35 BERBASIS ARDUINO UNO SEBAGAI MEDIA PEMBELAJARAN FISIKA
}

\author{
Hardi Hamzah ${ }^{1, a}$, Musdar $\mathbf{M}^{2, \mathrm{~b}}$, Hasrul ${ }^{3, \mathrm{c}}$ \\ 1,2,3 Universitas Sulawesi Barat

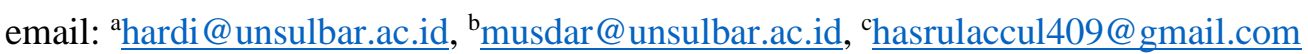

\begin{abstract}
Abstrak
Penelitian ini merupakan penelitian pengembangan dengan menggunakan metode Research and Development $(\mathrm{R} \& \mathrm{D})$ dan model Borg and Gall dengan pembatasan langkah penelitian sampai pada langkah ketujuh. Instrumen yang digunakan dalam penelitian ini adalah angket validasi ahli materi, angket validasi ahli media, angket respon peserta didik dan angket respon guru fisika. Aspek kevalidan ditinjau dari hasil penilaian validator yaitu validasi ahli media untuk alat ukur suhu diperoleh persentase rata-rata sebesar $91,67 \%$ dengan kategori sangat valid dan rata-rata persentase validasi buku panduan sebesar 95,42\% dengan kategori sangat valid serta validasi ahli materi untuk alat ukur suhu diperoleh rata-rata persentase $96.53 \%$ dengan kategori sangat valid dan persentase rata-rata validasi buku panduan sebesar sebesar 93,96\% dengan kategori sangat valid. Aspek kepraktisan ditinjau dari hasil respon guru fisika menunjukkan bahwa alat ukur suhu berada pada persentase $90,77 \%$ dengan kategori sangat praktis dan rata- rata persentase terhadap buku panduan sebesar $86,11 \%$ dengan kategori sangat praktis. Aspek keefektifan diperoleh dari hasil respon peserta didik terhadap alat ukur suhu menggunakan sensor LM35 berbasis Arduino Uno dengan persentase rata-rata sebesar $75.00 \%$ dengan kategori efektif dan persentase rata-rata untuk buku panduan sebesar 83,56\% dengan kategori sangat efektif. Dengan demikian penelitian ini diperoleh bahwa alat ukur suhu menggunakan sensor LM35 berbasis Arduino Uno dinyatakan layak berdasarkan aspek kevalidan, keefektifan dan kepraktisan.
\end{abstract}

Kata kunci: Alat Ukur Suhu, Radiasi Benda Hitam, Arduino Uno, LM35

\section{DEVELOPMENT OF A TEMPERATURE MEASURING INSTRUMENT USING AN ARDUINO UNO-BASED LMBS SENSOR AS A PHYSICS LEARNING MEDIA}

\begin{abstract}
This research is a development research using the Research and Development $(R \& D)$ design and the Borg and Gall model with the limitation of research steps up to the seventh step. The instruments used in this study were a material expert validation questionnaire, a media expert validation questionnaire, a student response questionnaire and a physics teacher response questionnaire. Aspects of validity in terms of the results of the validator's assessment, namely the validation of media experts for temperature measuring instruments obtained an average percentage of $91.67 \%$ with a very valid category and an average percentage of guide book validation of $95.42 \%$ with a very valid category and material expert validation for temperature measuring instruments obtained an average percentage of $96.53 \%$ with a very valid category and an average percentage of guide book validation of $93.96 \%$ with a very valid category. The practical aspect in terms of the results of the physics teacher's response shows that the temperature measuring instrument is in the percentage of $90.77 \%$ in the very practical category and the average percentage against the guidebook is $86.11 \%$ in the very practical category. The effectiveness aspect is obtained from the results of the student's response to the temperature measuring instrument using the Arduino Uno-based LM35 sensor with an average percentage of $75.00 \%$ in the effective category and the average percentage for the manual of $83.56 \%$ in the very effective category. Thus, this
\end{abstract}

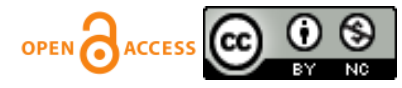


study found that the temperature measuring instrument using the Arduino Uno-based LM35 sensor was declared feasible based on the aspects of validity, effectiveness and practicality.

Keywords: Temperature Measuring Instrument, Black Body Radiation, Arduino Uno, LM35

\section{PENDAHULUAN}

Teknologi merupakan fasilitas dan penunjang utama untuk terlaksananya suatu proses pendidikan baik pada pendidikan formal maupun pendidikan nonformal. Pernyataan ini didukung penelitian yang dilakukan oleh Budiman tahun yang menyatakan bahwa teknologi merupakan penopang utama dalam tercapainya suatu pendidikan sehingga terciptanya suasana belajar yang mampu meningkatkan kualitas belajar bagi peserta didik. Pada saat ini perkembangan teknologi sangat cepat dan meluas ke segala bidang salah satunya dalam dunia pendidikan [1].

Sekolah menengah atas (SMA) merupakan salah satu jenjang pendidikan formal yang dalam proses pembelajarannya dilakukan secara terstruktur sehingga memperoleh sumber daya manusia yang berkualitas dan memiliki daya saing tinggi. Pada tahap SMA peserta didik memiliki daya pikir yang sedang berkembang dan semangat keingintahuan yang tinggi dalam menuntut ilmu [2]. Maka dari itu salah satu mata pelajaran wajib diajarkan di SMA yang dapat menunjang potensi peserta didik adalah mata pelajaran fisika. Fisika merupakan salah satu mata pelajaran yang merupakan bagian dari sains yang isi materinya membahas tentang fenomena-fenomena alam yang erat kaitannya dengan kehidupan sehari-hari manusia [3].

Mata pelajaran fisika dalam penyajian materinya bersentuhan langsung dengan kehidupan sehari-hari yang mempelajari materi beserta geraknya yang diharapkan untuk mampu menyelesaikan masalah berkaitan dengan alam sekitar. Pernyataan ini sejalan dengan penelitian yang menyatakan bahwa tuntutan kurikulum pada mata pelajaran fisika pada dasarnya adalah untuk mengantarkan peserta didik memahami konsep-konsep fisika dan mampu menerapkan dalam kehidupan sehari-hari [4]. Untuk lebih memudahkan dalam memahami dan mengingat materi-materi tersebut, maka harus dibarengi praktikum dengan menggunakan alat ukur sesuai dengan materi yang diajarkan. Hasil tes yang dilakukan menggambarkan bahwa peserta didik akan lebih memahami dan mengingat konsep materi yang dipelajari jika materi tersebut dibarengi dengan praktikum dan penelitian yang dilakukan oleh Pratiwi tahun 2020 yang mengatakan bahwa pentingnya dilaksanakan kegiatan praktikum untuk meningkatkan pemahaman terhadap materi fisika [5][6].

Materi radiasi benda hitam merupakan sub pokok bahasan pada materi yang dibahas pada kelas XII IPA untuk jenjang SMA Materi radiasi benda hitam dalam penyajian materinya agar terjalin proses pembelajaran langsung yang bermakna maka harus dibarengi dengan praktikum. Pengalaman langsung kepada peserta didik adalah dengan cara melaksanakan praktikum di Laboratorium atau tempat praktikum [7]. Pada pokok bahasan yang sering dijadikan topik praktikum untuk mencapai tuntutan kompetensi dasar (KD) adalah penentuan konstanta Boltzmann serta hubungan antara energi radiasi dan perubahan suhu. Sekolah menengah atas pada umumnya, masih menggunakan media sederhana dalam melaksanakan praktikum radiasi benda hitam seperti meletakkan es batu di bawah kaleng yang berbeda warna. Namun di beberapa sekolah jarang dilaksanakannya praktikum bahkan tidak dilakukannya praktikum karena keterbatasan alat ukur.

Beberapa penelitian sebelumnya mengenai pemanfaatan mikrokontroler Arduino uno dalam kehidupan sehari-hari dan sebagai media pembelajaran seperti penggunaan mikrokontroler dalam pengembangan media, penelitian yang mengembangkan sound level meter berbasis Arduino uno [8], sejalan dengan penelitian tersebut penelitian dengan menggunakan mikrokontroler Arduino uno sebagai pengolah data analog menjadi data digital [9]. Pengembangan media pembelajaran berbasis Arduino uno juga telah dilakukan dengan mengembangkan osiloskop sederhana berbasis Arduino uno [10]. Selain pengembangan media pembelajaran sebagai media pembelajaran juga dikembangkan alat pengukur $\mathrm{pH}$ air minum untuk menguji kelayakan konsumsi air minum di sepanjang sungai mandar [11]. 
Dalam mengimbangi perkembangan teknologi saat ini yang begitu cepat dan meluas, harusnya lebih sering menggunakan alat ukur yang digital. Namun seperti yang diketahui, alat ukur suhu digital harganya yang cukup mahal, sehingga menjadi penghambat untuk pengadaan alat ukur digital tersebut. Untuk mengurangi harga pengadaan alat tersebut maka sebagai tenaga pengajar harus bisa mengembangkan alat yang harganya lebih murah. Salah satu cara untuk mengembangkan alat ukur suhu digital adalah dengan memanfaatkan komponenkomponen elektronika salah satunya adalah Arduino.

\section{METODE}

\section{Jenis Penelitian}

Penelitian ini merupakan penelitian pengembangan yang menggunakan metode penelitian dan pengembangan (Research and development dengan model Borg and Gall yang dimodifikasi oleh Sugiyono. Model Borg and Gall yang dimodifikasi oleh sugiyono ini terdiri dari 10 langkah penelitian tetapi peneliti membatasi langkah-langkah penelitian pengembangan dari sepuluh langkah menjadi tujuh langkah, dikarenakan mengingat waktu penelitian yang tersedia dan kesempatan yang terbatas. Prosedur yang dilakukan peneliti yaitu: 1) Potensi dan Masalah, 2) Pengumpulan Data, 3) Desain Produk, 4) Validasi desain, 5) Perbaikan Desain, 6) Uji coba produk, 7) Revisi produk. Pembatasan langkah ini sejalan dengan yang dilakukan [12] yang menyatakan bahwa dapat dilakukan pembatasan dalam penelitian dengan skala kecil termasuk dalam membatasi langkah-langkah penelitian yang sudah ada.

\section{Waktu dan Tempat Penelitian}

Penelitian ini dilakukan di SMAN 1 Tapalang pada semester ganjil 2020/2021. Adapun waktu penelitian dilakukan mulai dari bulan April 2020 sampai dengan Desember 2020.

\section{Subjek Penelitian}

Subjek penelitian ini yaitu peserta didik kelas XII IPA 2 SMA Negeri 1 Tapalang yang berjumlah 12 orang.

\section{Prosedur}

Dalam pengambangan alat ukur suhu ini prosedur pengembangan yang yang dilakukan terdiri atas beberapa tahap sesuai yang disebutkan sebelumnya. Tahap-tahap pengembangan dipaparkan sebagai berikut:

\section{Potensi dan Masalah}

Penelitian dan pengembangan ini dilatar belakangi oleh potensi dan masalah. Potensi dan masalah dalam penelitian pengembangan ini adalah pada SMAN 1 Tapalang kurangnya ketersediaan alat suhu yang bisa digunakan dalam praktikum radiasi benda hitam. Selain dari kurangnya ketersediaan alat, pada proses praktikum dengan menggunakan media sederhana juga terbatas pada data yang diperoleh yaitu hanya sebatas pada gejalah fisis radiasi benda hitam.

\section{Pengumpulan data}

Setelah menemukan sebuah potensi dan masalah lengkap dan jelas maka tahapan selanjutnya yaitu mengumpulkan sumber referensi yang menunjang pengembangan alat ukur suhu menggunakan LM35 berbasis Arduino Uno. Sumber ini berasal dari jurnal, buku dan internet.

\section{Desain produk}

Perancangan alat ukur ini merupakan tindak lanjut dari permasalahan yang didapat saat observasi dan wawancara di sekolah SMAN 1 Tapalang. Hal ini menjadi tahap awal dalam pembuatan alat ukur suhu menggunakan sensor LM35 berbasis Arduino Uno yang ditawarkan sebagai solusi. Tahap perancangan ini dilakukan agar pembuatan alat dibuat secara terstruktur sehingga menghasilkan alat yang layak digunakan dan mampu menjadi solusi dari permasalahan yang ada. Pada tahap ini perancangan akan dilakukan terhadap alat ukur yang dikembangkan.

\section{Validasi}

Kegiatan ini merupakan kegiatan validasi dari ahli untuk menguji kevalidan alat ukur suhu yang dikembangkan. Uji kevalidan ini terdiri dari uji ahli materi dan uji ahli media, dengan mengisi lembar validasi yang telah disediakan untuk mendapatkan nilai dan tanggapan terhadap alat ukur yang dikembangkan mengenai keterkaitan dengan bahan ajar, ketahanan alat, keakuratan alat, efisiensi alat, estetika, keamanan, format, bahasa dan isi.

\section{Revisi desain}

Pada tahap ini setelah validasi produk 
selesai dilakukan, maka langkah selanjutnya adalah memperbaiki desain yang dianggap masih kurang oleh ahli validator pada aspek alat ukur yang dikembangkan beserta dengan buku panduan. Perbaikan ini dilakukan berdasarkan masukan kedua validator dari ahli media dan ahli materi yang tertulis pada kolom saran yang disediakan di masing-masing lembar validasinya.

\section{Uji coba desain}

Setelah melakukan perbaikan produk berdasarkan hasil validasi alat, selanjutnya dilakukan uji coba alat. Tempat uji coba alat ukur suhu ini dilakukan di SMAN 1 Tapalang yang terdiri dari subjek penelitian yaitu satu orang guru dan 12 orang peserta didik kelas XII IPA 2. Jika hasil dari uji coba ini menghasilkan sangat baik atau baik maka akan menghasilkan produk akhir. Akan tetapi jika tidak menghasilkan respon baik dari peserta didik dan guru fisika maka akan dilakukan revisi ulang, untuk menjadi acuan dari hasil akhir adalah alat ukur termometer analog.

\section{Revisi produk}

Setelah melakukan perbaikan produk berdasarkan hasil validasi alat, selanjutnya dilakukan uji coba alat. Tempat uji coba alat ukur suhu ini dilakukan di SMAN 1 Tapalang yang terdiri dari subjek penelitian yaitu satu orang guru dan 12 orang peserta didik kelas XII IPA 2. Jika hasil dari uji coba ini menghasilkan sangat baik atau baik maka akan menghasilkan produk akhir. Akan tetapi jika tidak menghasilkan respon baik dari peserta didik dan guru fisika maka akan dilakukan revisi ulang, untuk menjadi acuan dari hasil akhir adalah alat ukur termometer analog.

\section{Teknik Analisis Data}

Dalam penelitian ini teknik analisis data yang digunakan ada dua yaitu analisis deskriptif kualitatif dan analisis deskriptif kuantitatif yaitu sebagai berikut:

\section{Analisis deskriptif kualitatif}

Analisis ini digunakan untuk merevisi alat ukur yang dikembangkan berdasarkan hasil wawancara, kritik dan masukan dari ahli materi, ahli media, dan guru fisika.

\section{Analisis deskriptif kuantitatif}

Analisis ini digunakan untuk menganalisis hasil uji coba dan kalibrasi alat ukur suhu menggunakan sensor LM35 berbasis Arduino Uno. Analisis ini dilakukan dengan menghitung kesalahan yang dilakukan dengan membandingkan selisih antara nilai kesalahan terbatas terhadap nilai aktual yang ditetapkan. Nilai aktual yang ditetapkan ini merupakan hasil pengukuran dari termometer analog. Rumus mencari persentase kesalahan yang terjadi pada alat ukur yang dikembangkan menurut sebagai berikut:

$$
\% \text { Kesalahan }=\frac{\text { nilai diukur }- \text { nilai sebenarnya }}{\text { nilai sebenarnya }} \times 100
$$

Analisis validasi ahli dan respon pengguna

Teknik analisis data dari perhitungan ini menggunakan angket dari uji validasi ahli media, ahli materi, angket respon peserta didik dan guru fisika. Uji validasi oleh para ahli dan respon peserta didik ini disajikan dalam bentuk angket menggunakan rating scale dengan kriteria terdiri atas 4 item yaitu sebagai berikut:

Tabel 1. Tingkat Penilaian

\begin{tabular}{lll}
\hline No & Angka & Makna kualitatif \\
\hline 1 & 4 & $\begin{array}{l}\text { Sangat valid, sangat praktis } \\
\text { dan sangat efektif dapat } \\
\text { digunakan tanpa revisi. }\end{array}$ \\
\hline 2 & 3 & $\begin{array}{l}\text { Valid, praktis dan efektif } \\
\text { dapat digunakan tanpa } \\
\text { direvisi. }\end{array}$ \\
\hline 3 & 2 & $\begin{array}{l}\text { Tidak valid, tidak praktis dan } \\
\text { tidak efektif disarankan tidak } \\
\text { dipergunakan karena perlu } \\
\text { direvisi. }\end{array}$ \\
\hline 4 & 1 & $\begin{array}{l}\text { Sangat tidak valid, sangat } \\
\text { tidak praktis dan sangat } \\
\text { efektif tidak boleh } \\
\text { digunakan. }\end{array}$ \\
& &
\end{tabular}

Untuk analisis validasi ahli media, ahli materi hasil respon guru fisika dan hasil respon peserta didik dilakukan dengan menggunakan rumus sebagai berikut:

$$
\%=\frac{\text { jumlah hasil pengumpulan data }}{\sum \quad \text { responden } x \sum \text { item } 4} \times 10
$$

\section{HASIL DAN DISKUSI}

Hasil penelitian dari kelayakan alat ukur suhu menggunakan sensor LM35 berbasis Arduino Uno yang ditinjau dari kevalidan, kepraktisan dan keefektifan. Pengembangan alat 
ukur suhu menggunakan sensor LM35 berbasis Arduino Uno ini terdiri dari dua bagian yaitu, bagian alat ukur suhu dan buku panduan. Kedua dari bagian ini semuanya dilakukan uji kevalidan, kepraktisan dan keefektifan untuk menentukan kelayakan dari alat ukur suhu menggunakan sensor LM35 berbasis Arduino Uno yang dikembangkan.

Kelayakan alat ukur suhu menggunakan sensor LM35 berbasis Arduino Uno berdasarkan aspek validitas diperoleh dari validasi ahli media dan ahli materi. Validasi ahli media dan ahli materi ini masing-masing terdiri dari dua validator. Masing-masing validator tersebut memvalidasi alat ukur suhu yang terdiri dari dua bagian, yaitu bagian alat ukur suhu dan bagian buku panduan. Validasi ini menggunakan angket yang terdiri dari beberapa aspek penilaian. Ahli media terdiri dari enam aspek penilaian alat ukur suhu dan tiga aspek penilaian buku panduan. Ahli materi terdiri dari tiga aspek penilaian alat ukur dan lima aspek penilaian buku panduan. Hasil validasi rata-rata alat ukur suhu untuk setiap aspek penilaian oleh ahli media ditampilkan pada gambar 1 berikut:

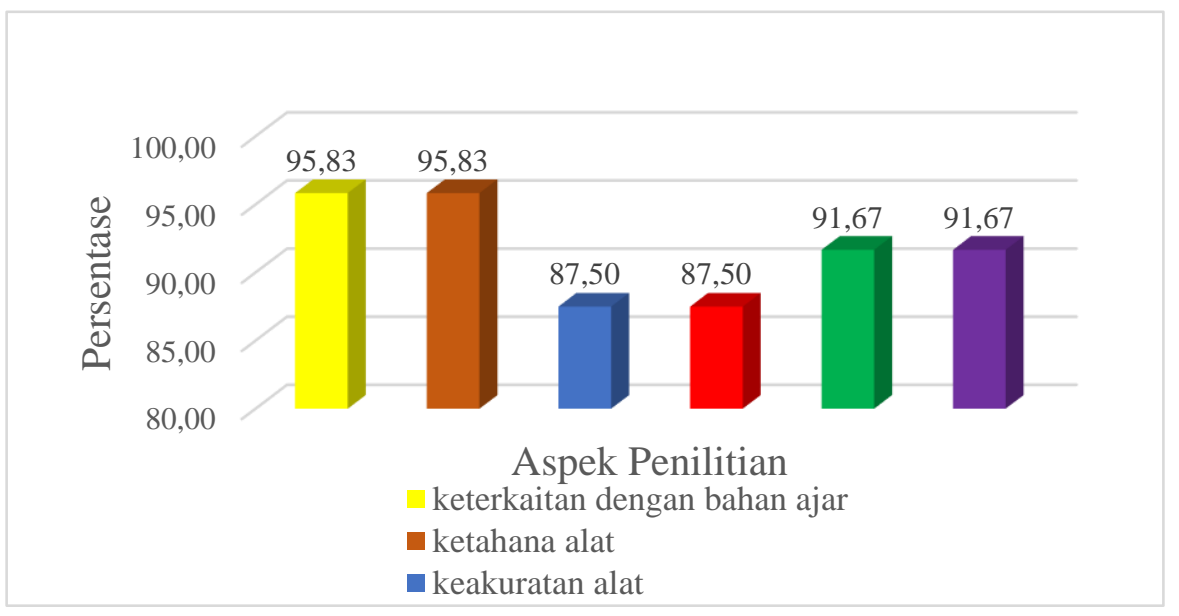

Gambar 1. Diagram Persentase Validasi Rata-Rata Alat Ukur Suhu Ahli Media

Tingkat kevalidan untuk setiap aspek penilaian yaitu keterkaitan dengan bahan ajar berada pada kategori sangat valid ketahanan alat berada pada kategori sangat valid, keakuratan alat berada pada kategori sangat valid, efisiensi alat berada pada kategori sangat valid, estetika berada pada kategori sangat valid, dan keamanan berada pada kategori sangat valid. Hasil tersebut diperoleh persentase rata-rata berada pada kategori sangat valid. Hasil validasi rata-rata buku panduan untuk setiap aspek penilaian ditampilkan pada gambar 2 berikut:

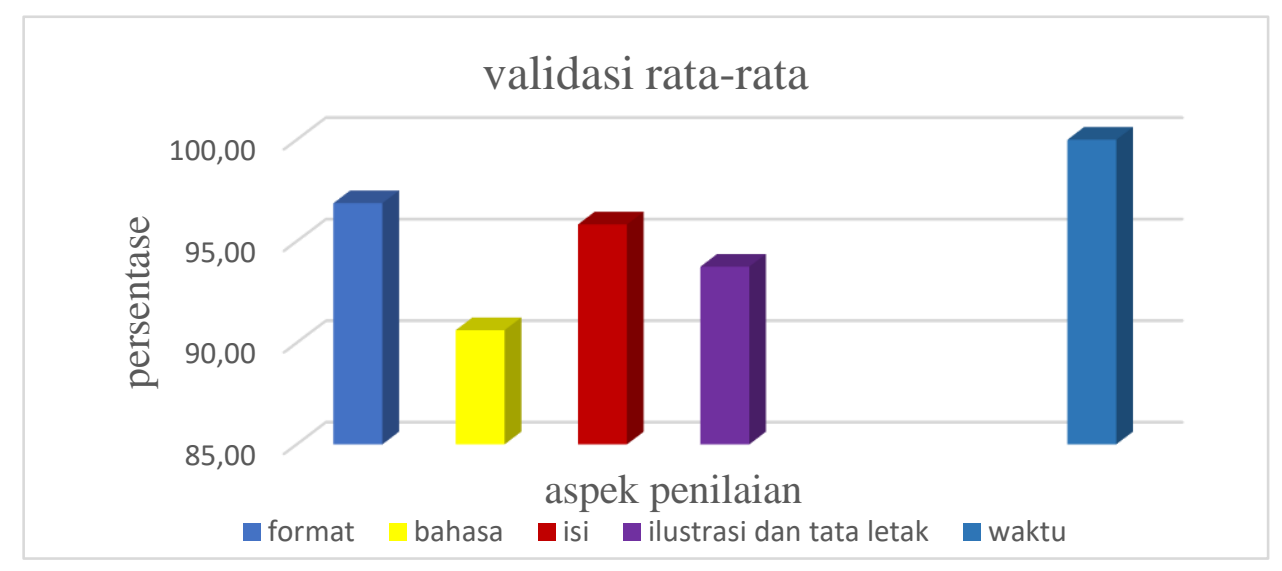

Gambar 2. Diagram Persentase Validasi Rata-Rata Buku Panduan Ahli Media

Dengan tingkat kevalidan setiap aspeknya yaitu format berada pada kategori sangat valid, bahasa berada pada kategori sangat valid, isi berada pada kategori sangat 
valid, ilustrasi dan tata letak berada pada kategori sangat valid serta waktu berada pada kategori sangat valid. Hasil tersebut diperoleh kevalidan buku panduan dengan kategori sangat valid. Selain dari validasi ahli media juga dilakukan validasi ahli materi.

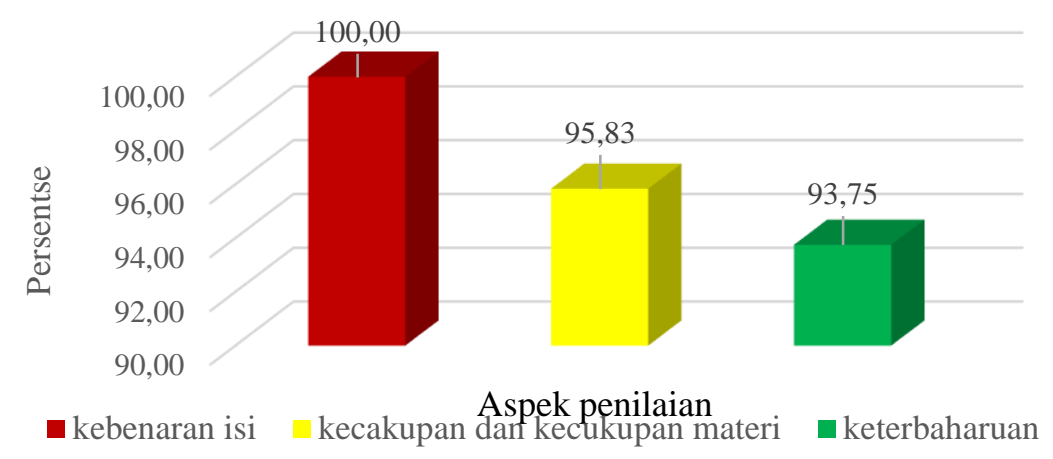

Gambar 3. Diagram Validasi Rata-Rata Alat Ukur Suhu oleh Ahli Materi

Tingkat kevalidan setiap aspek penilaian yaitu kebenaran isi berada pada kategori sangat valid, kecukupan dan kecukupan materi berada pada kategori sangat valid, dan keterbaharuan berada pada kategori sangat valid. Berdasarkan hasil tersebut diperoleh besar persentase rata-rata keseluruhan berada pada kategori sangat valid. Rata-rata hasil validasi buku panduan setiap aspek oleh ahli materi disajikan pada gambar 4 sebagai berikut.

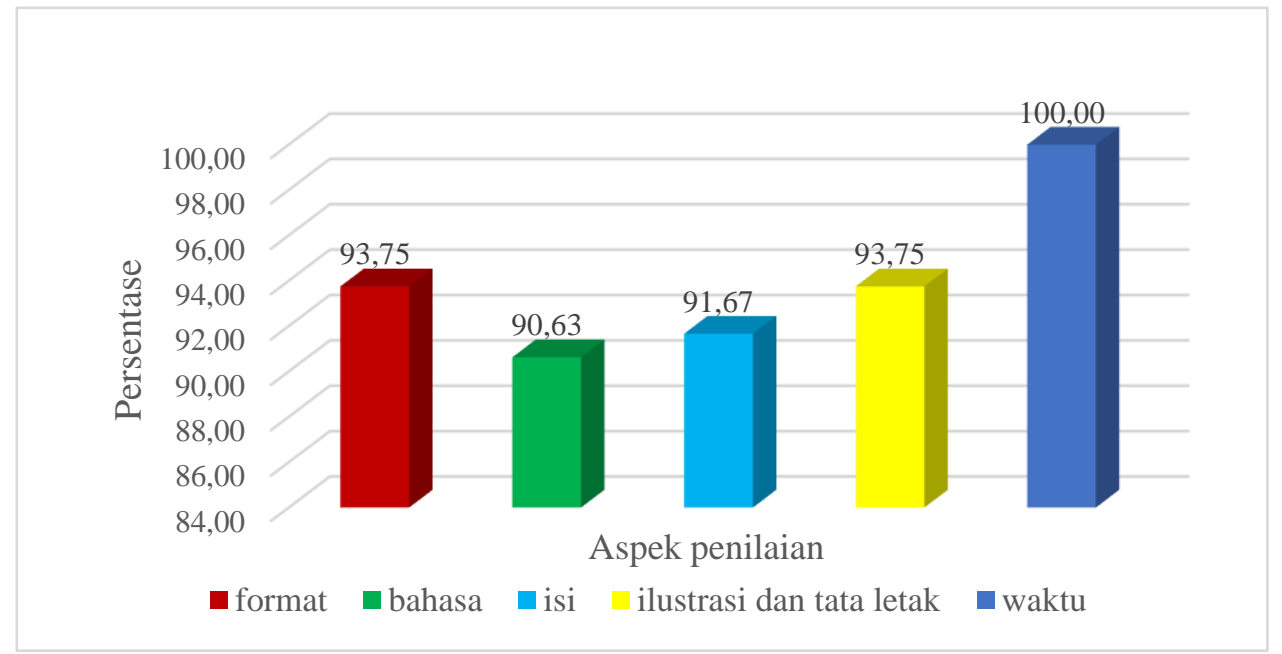

Gambar 4 Diagram Persentase Validasi Rata-Rata Buku Panduan Ahli Materi

Tingkat kevalidan setiap aspek penilaian yaitu format berada pada kategori sangat valid, bahasa berada pada kategori sangat valid, isi berada pada kategori sangat valid, ilustrasi dan tata letak berada pada kategori sangat valid, dan waktu berada pada kategori sangat valid. Hasil tersebut diperoleh persentase rata-rata validasi buku panduan oleh dua validator berada pada kategori sangat valid.

Berdasarkan hasil validasi oleh ahli materi dan ahli media diperoleh bahwa alat ukur suhu menggunakan sensor LM35 berbasis Arduino Uno berada pada kategori sangat valid dengan rentang persentase sebesar $89.17 \%$ $98.75 \%$. Berdasarkan analisis tersebut diperoleh bahwa pengembangan alat ukur suhu menggunakan sensor LM35 berbasis Arduino Uno dan sudah dapat dilakukan uji coba disekolah dengan terlebih dahulu memperbaiki atas saran yang diberikan oleh kedua validator. Pernyataan ini sejalan dengan penelitian yang dilakukan oleh Harlis \& Budiarti, (2017, p. 108) yang mengatakan bahwa berdasarkan hasil 
validasi yang berada pada kategori valid maka bahan ajar praktikum dan instrumen penilaian berbasis keterampilan proses sains yang dikembangkan sudah dapat digunakan dalam praktikum mikologi dan penelitian yang dilakukan oleh Hambali \& Yuliana, (2020, p. 125) yang mengatakan bahwa job sheet layak digunakan dalam praktikum setelah melalui uji validasi yang berada pada kategori valid.

Kepraktisan dinilai berdasarkan hasil respon guru fisika terhadap alat ukur suhu menggunakan sensor LM35 berbasis Arduino Uno. Penilaian kepraktisan ini sejalan dengan penelitian yang dilakukan oleh Prabowo et al.,
(2016, p. 1095) yang mengatakan bahwa penilaian kepraktisan dapat diperoleh dari hasil respon guru fisika. Respon guru fisika ini diperoleh dengan mengisi angket respon guru fisika terhadap alat ukur suhu menggunakan sensor LM35 berbasis Arduino Uno yang terdiri dari dua bagian yaitu bagian alat ukur suhu dan bagian buku panduan.

Setelah dilakukan analisis diperoleh bahwa respon guru fisika terhadap alat ukur suhu yang terdiri dari tujuh aspek alat ukur suhu berada pada kategori sangat praktis seperti yang ditunjukkan pada gambar 5 sebagai berikut:

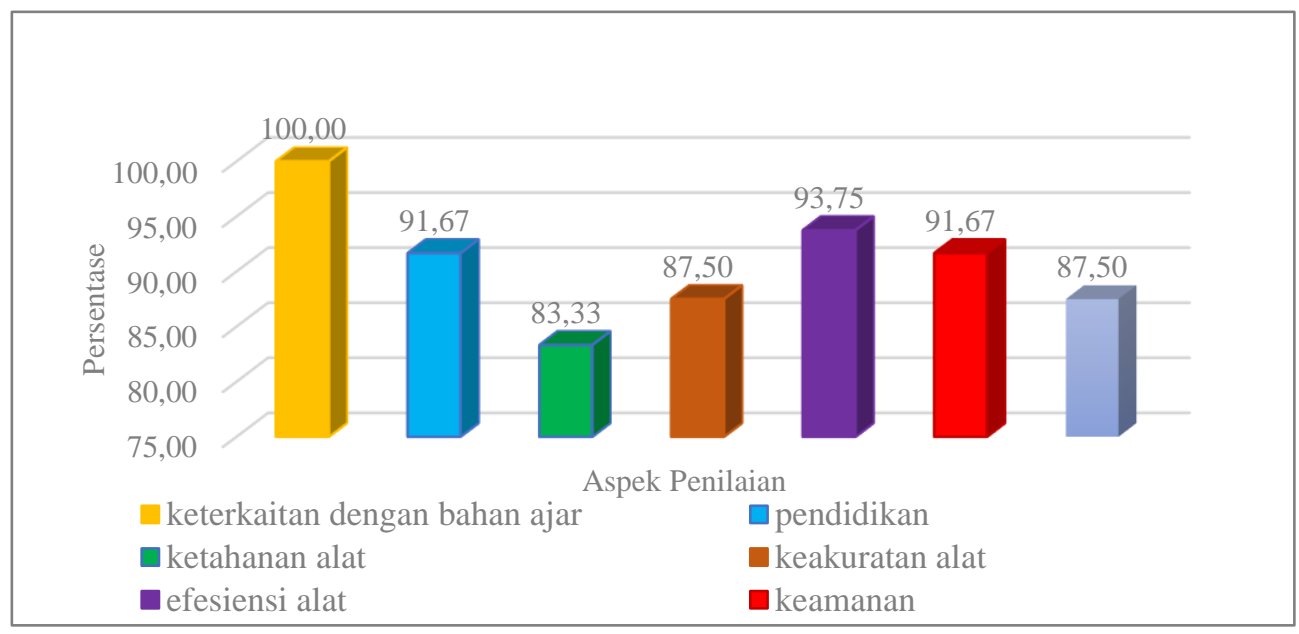

Gambar 5. Diagram Persentase Respon Guru Fisika terhadap Alat Ukur Suhu

Berdasarkan gambar 5 diperoleh bahwa keterkaitan dengan bahan ajar berada pada kategori sangat praktis, ketahanan alat berada pada kategori sangat praktis, efisiensi alat berada pada kategori sangat praktis, estetika berada pada kategori sangat praktis, pendidikan berada pada kategori sangat praktis, keakuratan alat berada pada kategori sangat praktis dan keamanan berada pada kategori sangat praktis. Hasil respon guru fisika terhadap buku panduan yang terdiri dari tiga aspek dapat dilihat pada gambar 6 yaitu sebagai berikut:

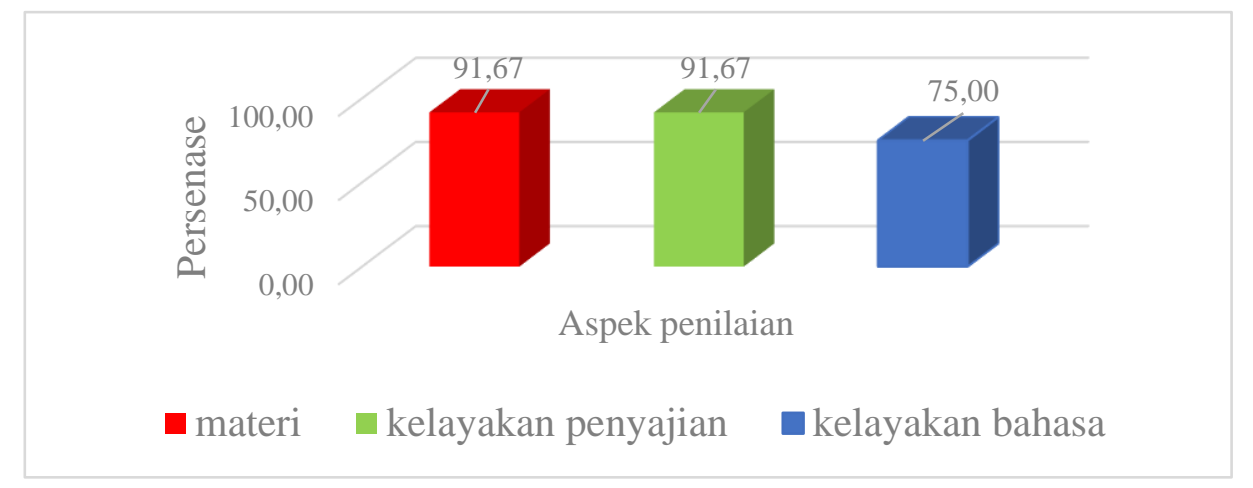

Gambar 6. Diagram Persentase Respon Guru Fisika terhadap Buku Panduan

Berdasarkan gambar 6 diperoleh bahwa buku panduan berada pada kategori sangat praktis dengan uraian per aspek yaitu, materi berada pada kategori sangat praktis, 
kelayakan penyajian berada pada kategori sangat praktis dan kelayakan bahasa berada pada kategori sangat praktis. Berdasarkan hasil analisis tersebut diperoleh bahwa pengembangan alat ukur suhu menggunakan sensor LM35 berbasis Arduino Uno memenuhi kriteria kepraktisan.

Keefektifan dari alat ukur suhu menggunakan sensor LM35 berbasis Arduino Uno diukur dari hasil respon peserta didik setelah melakukan praktikum bersama dengan teman kelompoknya. Ini sejalan dengan penelitian yang dilakukan oleh Sempana \& Anifah, (2017, p. 229) yang mengatakan bahwa efektivitas suatu media pembelajaran yang dikembangkan dapat dilihat dari hasil respon peserta didik. Hasil respon fisika terhadap alat ukur suhu menggunakan sensor LM35 berbasis Arduino Uno diperoleh dari pengisian angket respon siswa yang terdiri dari dua bagian yaitu bagian alat ukur suhu dan bagian buku panduan. Hasil respon peserta didik terhadap alat ukur suhu yang terdiri dari dua aspek penilaian dapat dilihat pada gambar 7 sebagai berikut:

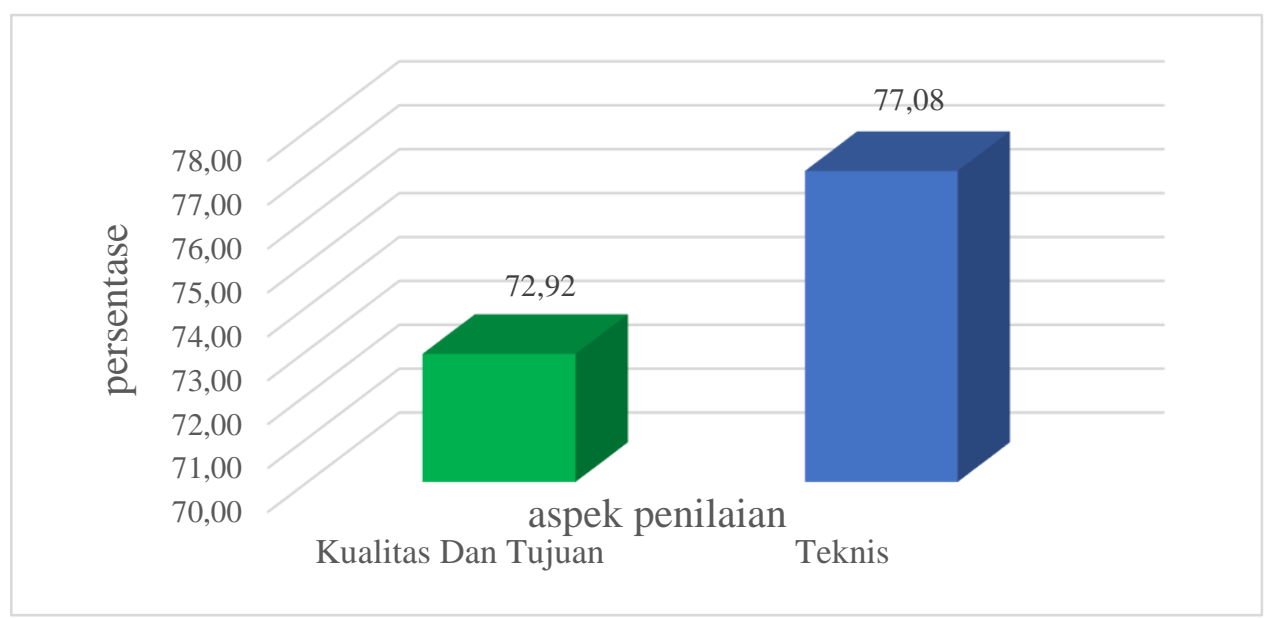

Gambar 7. Diagram Persentase Respon Peserta Didik terhadap Alat Ukur Suhu

Berdasarkan gambar 7 diperoleh ratarata respon peserta didik berada pada kategori efektif dengan uraian per aspek yaitu kualitas dan tujuan berada pada kategori efektif dan teknis berada pada kategori efektif. Pada buku panduan diperoleh hasil rata-rata respon peserta didik yang terdiri dari tiga aspek berada pada kategori sangat efektif seperti pada gambar 8 sebagai berikut:

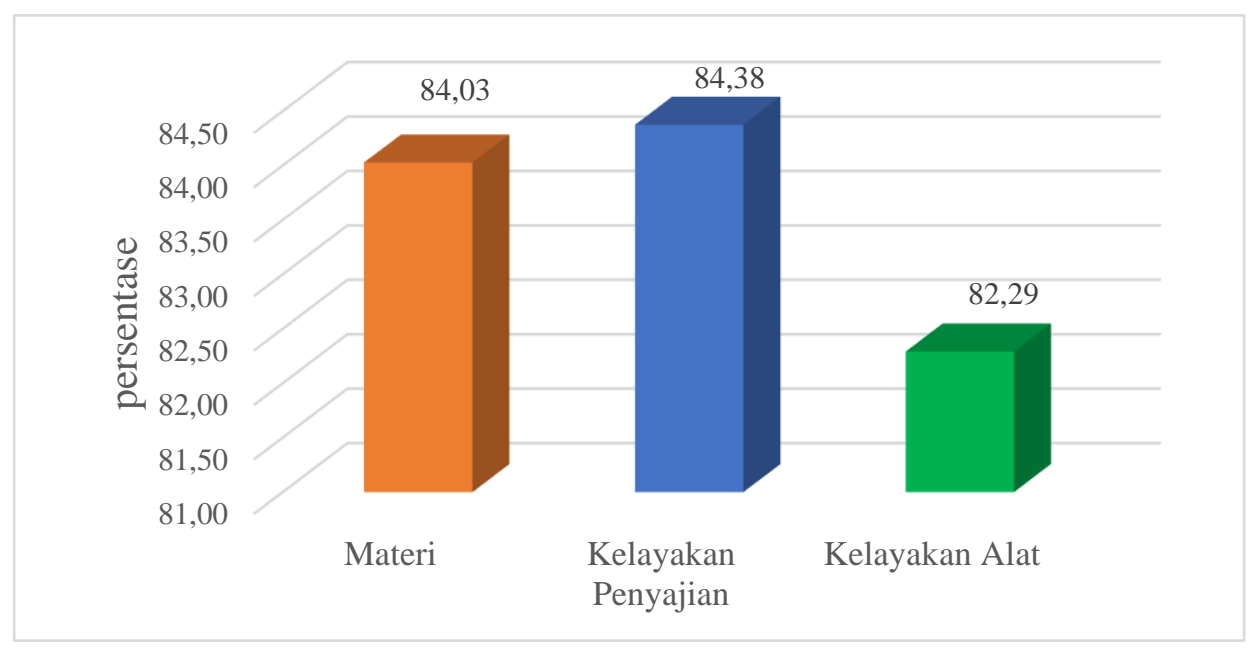

Gambar 8. Diagram Persentase Respon

Peserta Didik terhadap Buku Panduan Tersaji pada gambar dengan uraian per aspek yaitu, materi berada pada kategori sangat efektif, kelayakan penyajian berada pada 
kategori sangat praktis dan kelayakan alat berada pada kategori sangat efektif. Hasil analisis ini diperoleh bahwa alat ukur suhu menggunakan sensor LM35 berbasis Arduino Uno memenuhi kriteria efektif yang berada pada kategori efektif dan sangat efektif sehingga layak digunakan dalam pembelajaran fisika.

Berdasarkan uraian di atas diperoleh bahwa alat ukur suhu menggunakan sensor LM35 berbasis Arduino Uno memenuhi kriteria kelayakan alat sehingga dapat digunakan dalam pembelajaran fisika khususnya pada materi radiasi benda hitam. Pernyataan ini sejalan dengan penelitian yang dilakukan oleh [16] yang mengatakan bahwa alat yang dikembangkan layak digunakan dalam praktikum pembelajaran fisika berdasarkan dari hasil rata-rata validasi berada pada rentang $80 \%$ - $100 \%$ dan rata-rata hasil pengguna berada pada rentang $80 \%-100 \%$.

\section{SIMPULAN}

Penelitian pengembangan alat ukur suhu menggunakan sensor LM35 berbasis Arduino Uno ini dikembangkan dengan mengadaptasi metode Borg and Gall menjadi tujuh langkah penelitian dari sepuluh langka yang ada. Berdasarkan hasil penelitian yang dilakukan dapat disimpulkan bahwa alat ukur suhu menggunakan sensor LM35 berbasis Arduino Uno yang dikembangkan memenuhi kriteria valid, praktis dan efektif digunakan dalam pembelajaran fisika yakni pada materi radiasi benda hitam Saran dapat berupa masukan bagi peneliti berikutnya, dapat pula rekomendasi implikatif dari temuan penelitian.

\section{DAFTAR PUSTAKA}

[1] Budiman, H. (2014). Peran Teknologi Informasi dan Komunikasi Dalam Pendidikan. Pengertian MYSQL: Journal, 8 (I),31-43.

[2] Hidayatulah, A. H., Yushardi, \& Wahyuni, S. (2015). Pengembangan Bahan Ajar Berbasis WEB Interaktif Dengan Aplikasi E-Lerning Moodle Pada Pokok Bahasan Besaran Dan Satuan Di SMA. Jurnal Pendidikan Fisika, 4(2), 110-115.

[3] Saregar, A. (2016). Pembelajaran Pengantar Fisika Kuantum dengan
Memanfaatkan Media Phet Simulation dan LKM Melalui Pendekatan Saintifik: Dampak pada Minat dan penugasan konsep Mahasisea. Jurnal Ilmiah Pendidikan Fisika Al-Biruni, 5(1), 53-60.

[4] Warjanto, S. (2015). Pengembangan Media Pembelajaran Induksi Elektromagnetik. Prosiding Seminar Nasional Fisika (E- Journal), IV(1), 2326.

[5] Silaban, S. S., \& Utari, S. (2015). Analisis Didaktik Berdasarkan Profil Penguasaan Konsep Siswa pada Materi Suhu dan Kalor. Prosiding Simposium Nasional Inovasi Dan Pembelajaran Sains 2015 (SNIPS 2015), 521-524.

[6] Pratiwi, U. (2020). Pembelajaran Berbasis Praktikum Melalui Implementasi Metode School Assistance untuk Meningkatkan Pemahaman Sains Peserta Didik Pada Materi Hukum Hooke. Jurnal Ilmiah Pendidikan Fisika Tadulako Online, 8(1), 40-47.

[7] Agustianti, D., Rustana, C. E., \& Nasbey, H. (2015). Pengembangan Alat Praktikum Melde Sebagai Media Pembelajaran Fisika SMA. Prosiding Seminar Nasional Fisika (E-Journal) SNF2015, IV, 45-48.

[8] Hamzah, H., Agriawan, M. N., \& Abubakar, M. Z. (2020). Analisis Tingkat Kebisingan Menggunakan Sound Level Meter berbasis Arduino Uno di Kabupaten Majene. J-HEST: Journal of Health, Education, Economics, Science, and Tecnology, 3(1), 25-32.

[9] Prastika, L. R., Hamzah, H., Fatimah, \& Hendro. (2015). Detektor Ketebalan Kabut/Asap Berbasis Arduino Uno sebagai Antisipasi Terjadi Kecelakaan di Jalan Raya. Prosiding Simposium Nasional Inovasi Dan Pembelajaran Sains 2015 (SNIPS 2015), 2015(Snips), 97-100.

[10] Hamzah, H., Hajati, K., \& Darmawan. (2021). PENGEMBANGAN OSILOSKOP BERBASIS ARDUINO UNO SEBAGAI MEDIA PEMBELAJARAN FISIKA. Phydagogic: 
Jurnal Fisika dan Pembelajarannta, 3(1), 80-87. DOI: $\underline{10.31605 / p h y . v 3 i 2.1348}$

[11] Hamzah, H., Agriawan, M, N., Saldi, M, (2021). Uji Kelayakan Konsumsi Air Sungai Mandar Menggunakan Sensor pH Berbasis Arduino Uno. Jurnal Saintifik. 7(2), 161-171. DOI: https://doi.org/10.31605/saintifik.v7i2.339

[12] Rosdianto, H. (2018). RANCANG BANGUN ALAT PRAKTIKUM GERAK JATUH BEBAS DENGAN STOPWATCH OTOMATIS SEDERHANA. Jurnal Ilmu Pendidikan Fisika, 3(1), 20-23. https://doi.org/https://core.ac.uk/download /pdf/304293091.pdf

[13] Isa, A. R. M. (2017). Asas instrumentasi dan pengukuran fizik. Penerbit Universitas Teknologi Malaysia (W. M. S. W. Han (ed.); 1st ed.). Universiti Teknologi Malaysia

[14] Fuada, S. (2015). Pengujian Validitas Alat Peraga Pembangkit Sinyal (Oscillator) Untuk Pembelajaran Workshop Instrumentasi Industri. Prosiding Seminar Nasional Pendidikan, November, 854861.

[15] Sugiyono. (2017a). Metode Penelitian Dan Pengembangan (Research and Development). (ke-3). Alfabeta.

[16] Maryam, E., \& Fahrudin, A. (2020). Silampari Jurnal Pendidikan Ilmu Fisika PENGEMBANGAN SOUND CARD LAPTOP SEBAGAI ALAT. Silampari Jurnal Pendidikan Ilmu Fisika, 2(1), 2940.

https://doi.org/https://doi.org/10.31540/sjp if.v2i1.926 